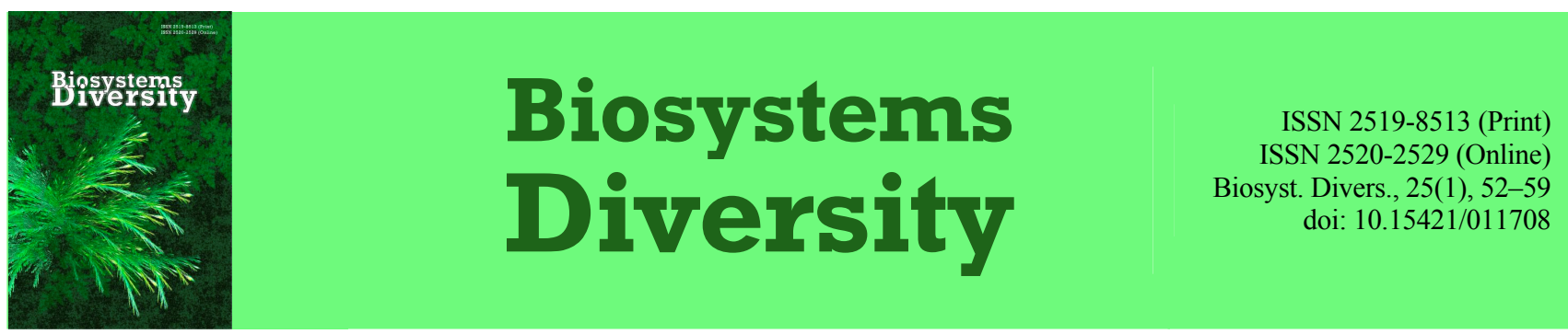

\title{
Assessment and prediction of the invasiveness of some alien plants in conditions of climate change in the steppe Dnieper region
}

\author{
Y. V. Lykholat*, N. A. Khromykh*, I. A. Ivan'ko*, V. L. Matyukha**, S. S. Kravets**, \\ O. O. Didur*, A. A. Alexeyeva*, L. V. Shupranova* \\ *Oles Honchar Dnipropetrovsk National University, Dnipro, Ukraine \\ **Institute of Grain Crops, Dnipro, Ukraine
}

Article info

Received 15.12.2016

Received in revised form 14.02.2017

Accepted 16.02.2017

Oles Honchar Dnipropetrovsk

National University,

Gagaryn Ave., 72,

Dnipro, 49010, Ukraine

E-mail:lykholat2006@ukr.net

Institute of Grain Crops,

Vernadsky Str., 14

Dnipro, 49000, Ukraine
Lykholat, Y. V., Khromykh, N. A., Ivan'ko, I. A., Matyukha, V. L., Kravets, S. S., Didur, O. O., Alexeyeva, A. A., \& Shupranova, L. V. (2017). Assessment and prediction of the invasiveness of some alien plants in conditions of climate change in the steppe Dnieper region. Biosystems Diversity, 25(1), 52-59. doi: 10.15421/011708

The flora of the steppe Dnieper region is characterized by an abundance of naturalized alien species, some of which colonised over the last decade. Climate change, associated primarily with increasing temperature, became clearly manifested in this period. We tested the hypothesis that there is an association between climate change and the initiation of invasiveness of some alien plant species in the steppe Dnieper region. For this purpose, comparative studies of the distribution boundaries of naturalized alien trees, shrubs and herbaceous plants were conducted. Along the research route numerous 5-10-year-old broadleaf linden trees (Tilia platyphyllos Scop.) were found in the man-made plantation communities of Dnipro city in areas with moist soil; seeded undergrowth was located at a significant distance from the adult linden plants. Numerous groups of young 7-10-year-old plants of the smoke trees (Cotinus coggygria Scop.), which had a seed origin, were found in the shelterbelt and urban recreational plantations. Young 10-12-year-old virginal and generative plants of the black cherry (Padus serotina Ehrh.) were found in large numbers in both the seminatural and artificial plant communities at great distances from the adult trees. The alien plant species common hackberry (Celtis occidentalis L.) showed the ability to form fairly sparse seminal seedlings, which was presented by the plants at the age of 4-7 years in both the natural and urban plant communities. The perennial herbaceous plant common milkweed (Asclepias syriaca L.) was found in the course of the research in ruderal habitats, urban plant communities, and also in the agrocoenoses. The common milkweed reached its greatest abundance in fields of winter crops, where the spread of this species was accompanied by a sharp decrease in the number of other species of segetal plants. Our study results confirm that the extension of the distribution boundaries of alien species over the last decade was not related to the ground conditions of the steppe Dnieper region. At the same time, changes in climatic conditions were favourable for some naturalized alien species because they have created the opportunity for seed reproduction of species away from the maternal plants. Alien species $C$. coggigria, P. serotina and A. syriaca were also the most sensitive to the influence of the climate changes. Consequently, these species have the greatest potential for increasing their level of invasiveness and endangering the biodiversity in the steppe Dnieper region under conditions of climate change. We suggest that a simultaneous initiation of invasiveness of these several alien species leads to an increase in the degree of threat to the diversity of natural plants in the region. The study results confirm the urgent need for analysis and forecasting of the consequences of introduction of alien species, in order to prevent the undesirable effects that this would bring for the region's native vegetation.

Keywords: warming; alien plants; seed reproduction; the initiation of invasiveness

\section{Оцінка і прогноз інвазійності деяких адвентивних рослин за впливу кліматичних змін у Степовому Придніпров’ї}

\author{
Ю. В. Лихолат*, Н. О. Хромих*, І. А. Іванько*, В. Л. Матюха**, С. С. Кравець**, \\ О. О. Дідур*, А. А. Алексєєва*, Л. В. Шупранова* \\ *Дніпропетровський національний університет імені Олеся Гончара, Дніпро, Украӥна \\ **Інститут зернових культур НААН України, Дніпро, Украӥна
}

Досліджено зміни меж розповсюдження натуралізованих адвентивних деревних, чагарникових і трав'янистих рослин у Степовому Придніпров’ї на фоні кліматичних флуктуацій упродовж останніх десятиліть. Показано наявність віддаленої від материнських рослин насіннєвої порослі липи широколистої (Tilia platyphyllos Scop.) у насадженнях м. Дніпро на ділянках із свіжуватими та свіжими гігротопами. Скумпія звичайна (Cotinus coggigria Scop.) утворила численний насіннєвий підріст у полезахисних насадженнях та міських рекреаційних зонах. У напівприродних фітоценозах і лісових насадженнях знайдено віргінільні та генеративні рослини черемхи пізньої (Рadus serotina Еhrh.) насіннєвого походження. У природних екотопах і міських фітоценозах зафіксовано насіннєву поросль каркасу західного (Celtis occidentalis L.). 
Виявлено проникнення ваточника сирійського (Asclepias syriaca L.) у міські фітоценози, а також різке зростання його чисельності в агроценозах, особливо у посівах озимих культур, де інвазія ваточника супроводжувалась зниженням чисельності інших сегетальних видів. Зроблено припущення, що саме кліматичні зміни останніх десятиліть створили для досліджених адвентивних видів сприятливі умови для формування життєздатного насіння та його проростання. Адвентивні види C. coggigria, P. serotina та A. syriaca виявили найбільшу чутливість до кліматичних змін, отже, мають високий потенціал щодо посилення інвазійності та загрози біорізноманіттю у Степовому Придніпров"ї. Наголошується на необхідності аналізу та прогнозування можливих віддалених наслідків інтродукції чужорідних рослинних видів.

Ключові слова: потепління; чужорідні рослини; насіннєве відтворення; ініціація інвазійності

\section{Вступ}

У флорі Дніпропетровської області сьогодні майже $17 \%$ видового складу припадає на фракцію адвентивних рослин, причому для деяких із них відмічено зростання рівня інвазійності протягом останніх 30-40 років (Baranovski et al., 2016). Аналогічна тенденція для чужорідних видів рослин виявлена у різних частинах світу (Thuiller et al., 2007; Bergstrom et al., 2009; Vila et al., 2009), що вказує на наявність загальних закономірностей виникнення феномену. Онтогенез рослин і просторове розповсюдження рослинних видів жорстко детермінується кліматом (Ramirez-Valiente et al., 2015). Отже, актуальні упродовж останніх десятиліть кліматичні зміни в напрямку підвищення температури та посушливості здатні внести суттєві корективи у розселення видів рослин (Bahuguna and Jagadish, 2015; Sperlich et al., 2015). Установлено (Thuiller, 2007), що попри різноманіття аспектів впливу кліматичних змін на природні угруповання, екосистеми та місцезростання, найбільш безпосередня дія зсув географічних діапазонів. Прогнозується (Pompe et al., 2010; Araujo et al., 2011; Jochner and Menzel, 2015), що у Західній і Центральній Європі внаслідок зростання температури та посухості загостриться проблема виживання рослин.

Зокрема, у Середземноморському регіоні може відбутися витіснення автохтонних лісових видів південними генотипами (Bussotti et al., 2015), у тому числі вічнозеленими видами рослин (Niinemets and Penuelas, 2008). Зміни кліматичних умов y різних регіонах нині спричиняють появу відмінностей у динаміці популяцій місцевих видів, а отже, у складі та структурі угруповань, трофічних зв'язках і функціонуванні екосистем у цілому (Gritti et al., 2006; Mund et al., 2010; Linder et al., 2014; Brygadyrenko and Nazimov, 2015; Brygadyrenko, 2016).

Зміни меж розповсюдження корінних видів за впливу кліматичних флуктуацій включають процеси, близькі до тих, що відбуваються під час розповсюдження чужорідних видів (Thuiller, 2007). Більше того, Walther et al. (2009) наголошують, що зміни клімату та біологічні інвазії - ключові процеси, які впливають на глобальне біорізноманіття та вказують на наявність зв'язку між двома процесами. Оскільки впливу кліматичних змін зазнають усі рослини певного місцезростання, то цілком ймовірно, що деякі види, як аборигенні, так і чужорідні, можуть за таких умов отримати переваги для свого розселення.

Нині вже існують свідчення того, що кліматичні зміни останніх десятиліть виявились сприятливими для деяких адвентивних видів і дозволили їм розповсюджуватися у регіонах, де раніше вони не мали шансів на виживання й відтворення. До прикладу, аналіз розплідників рослин у Свропі виявив численні садові різновиди, які виживали у регіонах, розташованих на 1000 км північніше, ніж вони раніше могли бути висаджені (Van der Veken et al., 2008). Багаторічні дослідження (Berger et al., 2007) підтвердили, що пом'якшені зимові умови останніх декількох десятиліть узгоджуються із трендом розширення 3 півдня на північ потенційних діапазонів та збільшення числа вічнозелених широколистяних порід, імовірним наслідком чого виявиться значна зміна складу та структури широколистяних лісів у різних частинах Європи.

У попередніх дослідженнях ми встановили, що у степовій зоні України автохтонні (Lykholat et al., 2016a) та адвентивні (Lykholat et al., 2016b) деревні рослини характеризуються надзвичайно високою чутливістю метаболічних процесів до мінливості мікроклімату та освітленості навіть у незначному діапазоні коливань. Зважаючи на континентальний характер ре- гіонального клімату, можна очікувати, що його зміни в напрямку посилення рис аридності мають бути важливим чинником впливу на межі розповсюдження рослинних видів.

Ми припустили, що деякі адвентивні рослинні види могли отримати переваги для виживання та розселення на території Степового Придніпров'я за умов кліматичних змін останніх десятиліть. Для перевірки гіпотези проведено порівняльні дослідження сучасних меж розповсюдження деяких адвентивних рослин, які кількома десятиліттями раніше були асоційовані лише 3 локальними місцезростаннями. Мета роботи полягала у виявленні та оцінюванні рівня зростання інвазійності адвентивних видів i прогнозуванні ймовірних наслідків цього процесу для складу та структури регіональної рослинності.

\section{Матеріал і методи досліджень}

Дослідження проведені протягом 2013-2016 рр. на території Дніпропетровської області $\left(47^{\circ} 32^{\prime}-49^{\circ} 11^{\prime} \mathrm{N}, 33^{\circ}-33^{\circ} 56^{\prime} \mathrm{E}\right)$, яка повністю розташована в межах Степового Придніпров'я, а також на території м. Дніпро. Об'єктами дослідження обрано адвентивні деревні та чагарникові види, які були висаджені в регіоні дослідження у лісонасадженнях різного призначення понад 50 років тому: черемха пізня (Padus serotina Ehrh.), липа широколиста (Tilia platyphyllos Scop.), каркас західний (Celtis occidentalis L.), скумпія звичайна (Cotinus coggigria Scop.). Серед трав'янистих видів досліджено стан інвазійності багаторічної рослини ваточник сирійський (Asclepias syriaca L.).

Біолого-екологічна характеристика та таксономія рослинних видів наведена відповідно до сучасної номенклатури, прийнятої в Україні (Mosyakin and Fedoronchuk, 1999; Barbarich and Horhota, 1952). Згідно із загальноприйнятими підходами (Blackburn et al., 2014), адвентивними вважали такі види, які внаслідок діяльності людини розселялись у регіонах, де раніше були відсутні. Визначення інвазійності адвентивних рослин проводили за критерієм (Richardson et al., 2000), згідно з яким інвазійними вважали натуралізовані у регіоні види, що виявили спроможність до розселення на далекі відстані від материнських рослин.

Відповідно до поставленої мети щодо оцінки та прогнозування наслідків впливу кліматичних змін на розповсюдження адвентивних рослинних видів, необхідно конкретизувати напрями та діапазон флуктуацій кліматичних параметрів для регіону проведення досліджень у відповідний період часу. Подібні дослідження (Pompe et al., 2014) виявили складні ефекти взаємодії між значеннями температури та вологості та розширенням ареалу. Беручи до уваги той факт, що більшість досліджень кліматичних змін орієнтована на наслідки підвищення температури (Walther et al., 2009; Bahuguna and Jagadish, 2015), ми провели порівняльний аналіз температурного режиму протягом вегетації рослин за період з 2013 по 2016 рік. За основу брали дані Гідрометеослужби у Дніпропетровській області. Флуктуації температури протягом останніх років реєстрували у відношенні до усереднених значень багаторічних досліджень (рис. 1).

Аналогічний аналіз проведено для виявлення напрямків та діапазону коливань місячної кількості опадів (рис. 2) та кількості посушливих днів (коли рівень відносної вологості був нижче $30 \%$ ) упродовж періоду вегетації за останні роки (рис. 3 ).

Відомо (Bowler et al., 2015), що вплив кліматичних змін на розвиток популяцій різних видів має варіативний характер. Це пояснюється видовими особливостями, такими як швидкість відтворення та пристосованість до певних умов середовища, зокрема надання переваги певному температурному режиму. 3 огляду 
на такий феномен ми аналізували стан інвазійності досліджених адвентивних видів з урахуванням регіонів їх походження та еколого-біологічних особливостей.

Ваточник сирійський (Asclepias syriaca L.) - багаторічна коренепаросткова трав'яниста рослина, яка належить до родини Asclepiadaceae та походить із Північної Америки (Pauková et al., 2013; Bacieczko and Borcz, 2015). Цей вид потребує мезотрофного рівня живлення та віддає перевагу середовищам із помірним зволоженням і достатнім освітленням, хоча й витримує затінення (Tarasov, 2005).

Скумпія звичайна (Cotinus coggygria Scop.) - чагарник або невелике дерево $з$ родини сумахові (Anacardiaceae). Вид походить із Середземноморського регіону, а його сучасний природний ареал має диз'юнктивний характер у межах південної та східної частин Європи й Азіі, у тому числі в Україні у Поліссі, Лісостепу, Криму. У степовій зоні України спостерігаються локальні природні ценопопуляції скумпії на території долини р. Сiверський Донець від м. Ізюм (Харківська обл.) до с. Криві Луки (Донецька обл.) (Barbarich and Horhota, 1952; Tarasov, 2005)

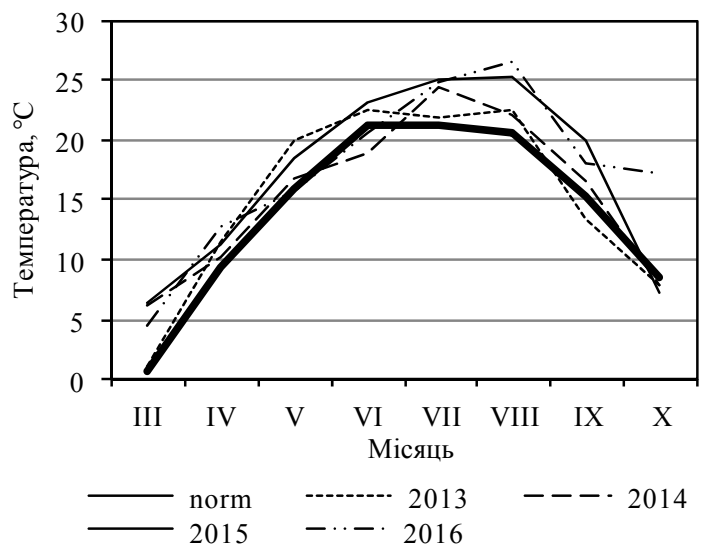

Рис. 1. Флуктуації температури повітря протягом періоду досліджень порівняно із середніми показниками багаторічних досліджень: norm - усереднені значення за багаторічний період досліджень (тут і далі)

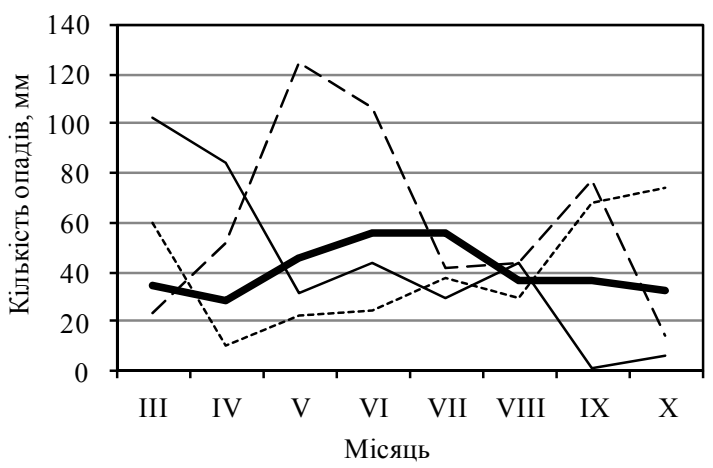

$\longrightarrow$ norm -.-.-.- $2013---2014 \longrightarrow 2015$

Рис. 2. Динаміка кількості опадів протягом періоду досліджень порівняно із середніми показниками багаторічних досліджень

Для Степового Придніпров'я C. coggygria не $\epsilon$ компонентом природної флори, а іï присутність у складі насаджень різного призначення - результат уведення в культуру. За класифікацією адвентивних видів скумпія звичайна у Степовому Придніпров $\dddot{i}$ - кенофіт (неофіт), ергазіофіт, епекофіт.

Деревний вид черемха пізня (Padus serotina (Ehrh.) Ag.) належить до родини розові (Rosaceae) та має північноамериканське походження (Barbarich and Horhota, 1952; Tarasov, 2005). Черемха пізня - кенофіт (неофіт), ергазіофіт, агріофіт. Північноамериканське походження має також каркас західний (Celtis occidentalis L.), який належить до родини в’язові (Ulmaceae) та характеризується як посухостійкий та морозовитривалий вид (Barbarich and Horhota, 1952; Tarasov, 2005). Для території Свропи - адвентивний вид, відомий у культурі з 1856 року. Має тенденцію до експансії (Barbarich and Horhota, 1952; Pyšek et al., 2012). За класифікацією адвентивних видів каркас західний кенофіт (неофіт), ергазіофіт, колонофіт.

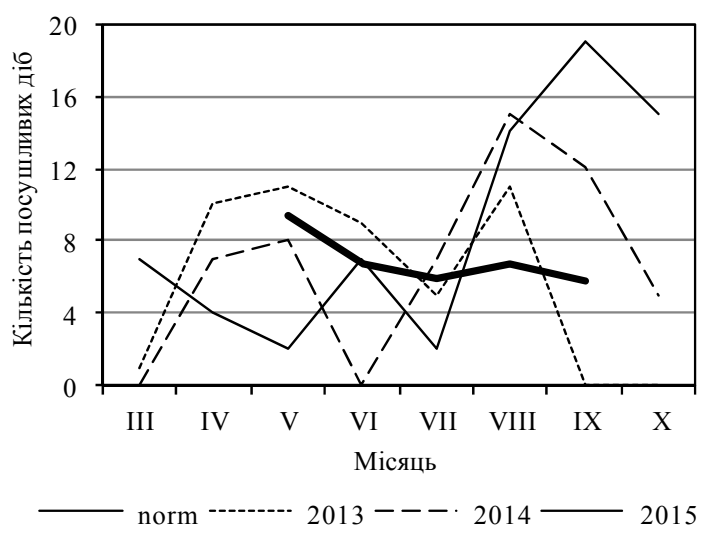

Рис. 3. Кількість посушливих діб за період досліджень порівняно із середніми показниками багаторічних досліджень

Геоботанічні дослідження проведені польовим маршрутним методом у складі Комплексної експедиції з вивчення лісів степової зони України Дніпропетровського національного університету імені Олеся Гончара. Статистичне опрацювання даних здійснювали шляхом розрахунку середнього арифметичного та його стандартної помилки.

\section{Результати та їх обговорення}

Порівняльний аналіз виявив суттєві зміни меж розповсюдження досліджуваних рослинних видів на території Дніпропетровської області та м. Дніпро упродовж останніх 30-40 років. На фоні кліматичних флуктуацій у багатьох районах області адвентивні види виявили тенденцію до збільшення чисельності та до розселення у нових місцезростаннях (рис. 4).

Ваточник сирійський. За результатами наших досліджень, поширення ваточника сирійського набуло значних масштабів на території Синельниківського, Дніпропетровського та Солонянського районів. У складі сегетальних угруповань A. syriaca як злісний бур'ян виявлено на площі 5-100 га у посівах різних культур, зокрема, пшениці озимої, ячменю озимого, рапсу озимого (рис. 4). Переважання ваточника сирійського саме у посівах озимих культур зумовлене комплексом причин, який включає еколого-біологічні особливості виду та специфічні умови агроценозів (табл. 1). Паростки A. syriaca 3'являються у травні, коли в агроценозах 3 озимими культурами вже не застосовується механізована обробка грунту, тож єдиним засобом впливу на небажану рослинність залишається тільки одноразова гербіцидна обробка. За таких умов рослини ваточника сирійського встигають утворити потужні підземні органи, а пошкоджену гербіцидами надземну частину швидко відновлюють завдяки відростанню пагонів від кореневища. Припускаємо, що додатковою складовою успішного розповсюдження A. syriaca в агроценозах, поряд із високою конкурентоздатністю адвентивного виду, може бути несприятлива спрямованість кліматичних флуктуацій для інших сегетальних видів. Наслідком одночасного впливу кліматичних та фітоценотичних чинників для деяких видів рослин може виявитись зниження їх чисельності, або навіть елімінація із сегетальних угруповань.

Саме така тенденція встановлена нами у посівах озимої пшениці, де протягом 2013-2016 рр. спостерігали зниження чисельності (у шт./м²) талабану польового (Thlaspi arvense L.) у 2,2 раза, щириці жминдовидної (Amaranthus blitoides S. Watson) - удвічі, лободи білої (Chenopodium album L.) - в 1,7 раза, 
мишію сизого (Setaria glauca (L.) Р. Beauv.) і зеленого (Setaria viridis (L.) P. Beauv.) - у 3,3 раза, у той час як чисельність A. syriaca збільшилась у 2,1 раза.

На території м. Дніпро локалітети ваточника сирійського зафіксовані у парку Дружби народів (рис. 5) під наметом акацієво-ясеневих насаджень у сухуватих та свіжуватих позиціях на лучно-чорноземних слабковилужених потужних малогумусних важкосуглинистих грунтах. Під час дослідження виявлено 7 куртин $A$. syriaca 3 чисельністю по 10-15 рослин у куртинах.

Упродовж 1970-1980-х років $A$. syriaca на території Дніпропетровської області виявлений як натуралізований вид у Синельниківському та Дніпропетровському районах у рудеральних місцезростаннях із частотою трапляння на рівні 3,5 одиниць за шестибальною шкалою (Tarasov, 2005). За архівними даними Ерастівської дослідної станції (розташована у П'ятихатському районі), поодинокі рослини ваточника сирійського виявлені у 1974 році у посівах ярого ячменю, а також ярої та озимої пшениці, де вдалося контролювати розповсюдження адвентивної рослини завдяки комплексу агротехнічних заходів. Виявлена нами тенденція до зростання рівня інвазійності ваточника сирійського підтверджує закономірність, згідно 3 якою найуспішніше вторгнення демонструють види, здатні пристосуватися до порушених ландшафтів 3 антропогенним домінуванням (Suarez and Tsutsui, 2008).

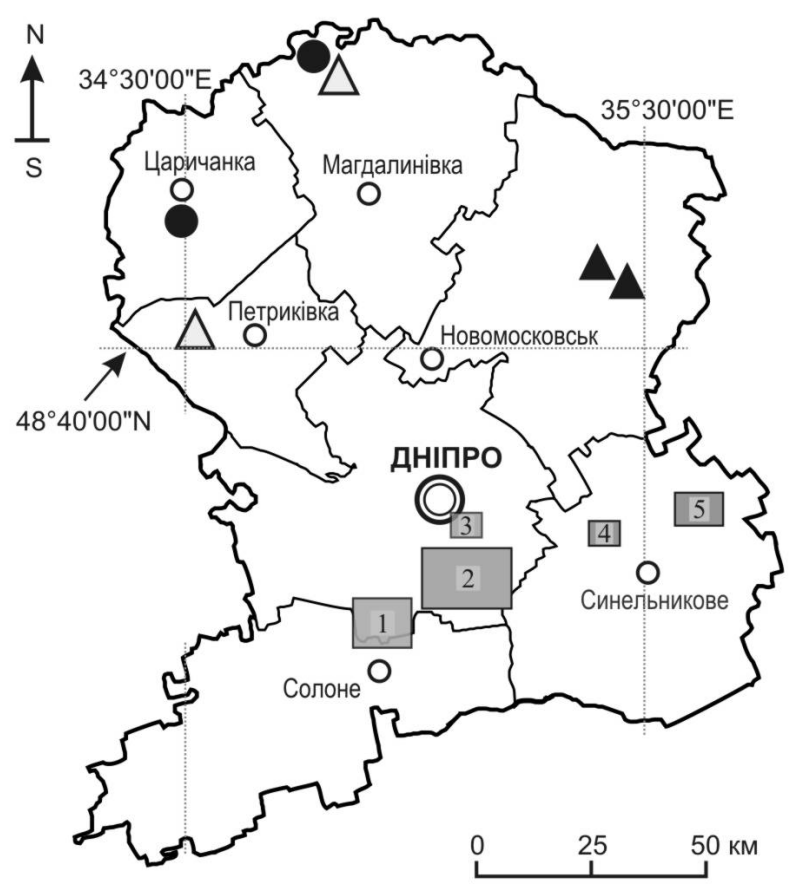

Рис. 4. Природні, напівприродні та штучні місцезростання Дніпропетровської області, в яких виявлено посилення інвазійності адвентивних рослинних видів:

- ваточник сирійський, $\boldsymbol{\Delta}$ - скумпія звичайна, $\bullet$ - каркас західний; $\Delta$ - черемха пізня; площа зі знахідкою:

1 - 50 га, 2 - понад 100 га, 3 - 6 га, 4-5-6 га, 5-20 га

\section{Таблиця 1}

Чисельність ваточника сирійського (шт./м²) у посівах культурних рослин (дослідне господарство «Дніпро», 2016 р.)

\begin{tabular}{lc}
\hline \multicolumn{1}{c}{ Культура } & Середня чисельність \\
\hline Пшениця озима (агроценоз 1) & $7,90 \pm 0,45$ \\
Пшениця озима (агроцено3 2) & $6,24 \pm 0,41$ \\
Ячмінь озимий & $4,18 \pm 0,36$ \\
Кукурудза & $3,50 \pm 0,29$ \\
\hline
\end{tabular}

Вивчення динаміки адвентивних видів у різних регіонах із помірним кліматом показало, що адвентивні види з високою конкурентоздатністю у нових умовах (Urban et al., 2012) та успішно натуралізовані адвентивні рослини (Arianoutsou et al.,
2013), незалежно від регіону їх походження, найчастіше зустрічаються одразу у декількох місцезростаннях, спричинюючи високий рівень гомогенізації регіональної флори. Припускаємо, що саме такі наслідки може мати розширення меж розповсюдження ваточника сирійського у Степовому Придніпров’і. Зроблений прогноз ураховує виявлену упродовж останніх років тенденцію до масштабного поширення адвентивного виду $A$. syriaca не тільки у рудеральних місцезростаннях, а й у агроценозах із застосуванням сівозміни, проведенням агротехнічних заходів і внесенням гербіцидів. Експансію ваточника сирійського у регіоні ми вважаємо прикладом неконтрольованих наслідків інтродукції чужорідних видів, адже $A$. syriaca завезений до Європи як технічна та декоративна рослина, але за певних умов із культури проник у природне середовище. Актуальність проблеми підтверджується застереженням (Niinemets and Penuelas, 2008) щодо необхідності кількісних оцінок глобальних наслідків садівництва та міського озеленення.

Липа широколиста. На території м. Дніпро дослідження дозволили зафіксувати початкові етапи процесу розширення меж розповсюдження липи широколистої (Tilia platyphyllos Scop.). Цей адвентивний для Степового Придніпров'я вид виявив здатність до формування насіннєвої порослі, яка знайдена у фітоценозах парку Дружби народів та парку Зелений Гай (рис. 5) на відстані кількох десятків метрів від дорослих рослин. На території обох парків молоді рослини липи широколистої виявлені на ділянках із свіжуватими та свіжими гігротопами на грунтах із високою трофністю - чорноземах звичайних лісополіпшених (парк Зелений Гай) та лучночорноземних (парк Дружби народів). Материнські дерева виду T. platyphyllos, висаджені понад 45 років тому, під час дослідження мали задовільний життєвий стан та успішно проходили всі фенофази від цвітіння до утворення насіння. Віковий стан молодих дерев у складі насіннєвої порослі липи широколистої коливався у досить широкому діапазоні (табл. 2).

\section{Таблиця 2}

Розподіл насіннєвого покоління липи широколистої за онтогенетичними групами (парк Зелений Гай)

\begin{tabular}{lccc}
\hline \multirow{2}{*}{ Показник } & \multicolumn{3}{c}{ Онтогенетична група } \\
\cline { 2 - 4 } & ювенільні & віргінільні & генеративні \\
\hline Вік, роки & $1-2$ & $5-8$ & $11-12$ \\
Висота, м & $0,51 \pm 0,12$ & $1,8 \pm 0,45$ & $4,1 \pm 0,48$ \\
Чисельність, $\%$ & 30 & 65 & 5 \\
\hline
\end{tabular}

Отримані результати вказують, що сприятливі умови для проростання насіння та виживання паростків T. platyphyllos склалися саме останніми роками. Ми вважаємо, що ключову роль в ініціації інвазійності натуралізованого у регіоні адвентивного виду відіграли зміни температури та рівня зволоженості упродовж періоду вегетації, оскільки едафічні та гідрологічні умови протягом минулих десятиліть помітних змін не зазнали. Припускаємо, що вплив підвищеної температури повітря (рис. 2) та кількості опадів у березні та червні упродовж попередніх років (рис. 3) виявився сприятливим для проростання насіння та успішного розвитку проростків липи широколистої. Кліматичні флуктуації під час вегетаційного періоду могли спричинити певні зсуви фенофаз у дорослих дерев T. platyphyllos, унаслідок чого вони утворили більш життєздатне насіння.

Отримані результати узгоджуються 3 даними фенологічних досліджень 542 рослинних видів, проведених у 19 європейських країнах (Menzel et al., 2006), які виявили, що загальні реакції рослин на зростання температури середовища полягали у більш ранньому розкритті бруньок (у $78 \%$ видів рослин) та затриманні настання періоду зміни кольору та опадання листя. Ті самі дослідження показали, що під час зростання температури у попередні місяці на $1{ }^{\circ} \mathrm{C}$ весняні фенологічні фази починались на 2,5 доби раніше, тоді як осінні фенофази наставали пізніше на одну добу. Аналогічні результати дав аналіз динаміки урбанофлори в Німеччині протягом останніх трьох століть, який вказує, що наразі у багатьох видів рослин цвітіння починається раніше та закінчуєть- 
ся пізніше; при цьому зросла частка видів, яким властиве раннє утворення листків навесні (Knapp et al., 2009).

Скумпія звичайна. Під час геоботанічних досліджень у протиерозійних і полезахисних насадженнях і в міських рекреаційних зонах зареєстровано зростання ступеня натуралізації та інвазійної здатності скумпії звичайної, яке відбулося протягом останніх років. У Новомосковському районі на околиці села Андріївка (рис. 4) у лісонасадженнях головного моніторингового профілю Присамарського науково-навчального біосферного стаціонару імені О. Л. Бельгарда виявили масове формування куртин молодих рослин скумпії звичайної чисельністю до 10 рослин та віком не більше семи років. Куртини C. coggygria знайдені під наметом дубово-ясеневих насаджень (Quercus robur L., Fraxinus excelsior L.) по схилах балки
Баштанна (N 4846'40.10" E 35²7'26.90") і масивних 60-річних монодомінантних насаджень дуба звичайного (табл. 3) на плакоpi (N 4845'26.26" Е 35³0'03.63"). За просторовим розміщенням куртини молодих рослин $C$. coggygria тяжіють до ділянок із деструкцією деревного намету та посиленою освітленістю нижніх фітогоризонтів на рівні 10,3\% від відкритих ділянок. За нашими даними, в указаних насадженнях скумпію звичайну висадили понад 50 років тому в перших зовнішніх рядах для зниження бічного освітлення. Відстань від локалітетів молодих рослин скумпії звичайної до дорослих особин складала 10-50 м, що свідчить про насіннєве походження порослі. Необхідно зауважити, що під час досліджень, проведених упродовж 20002005 років, наявність насіннєвої порослі скумпії звичайної під наметом тих самих лісонасаджень не зафіксовано.

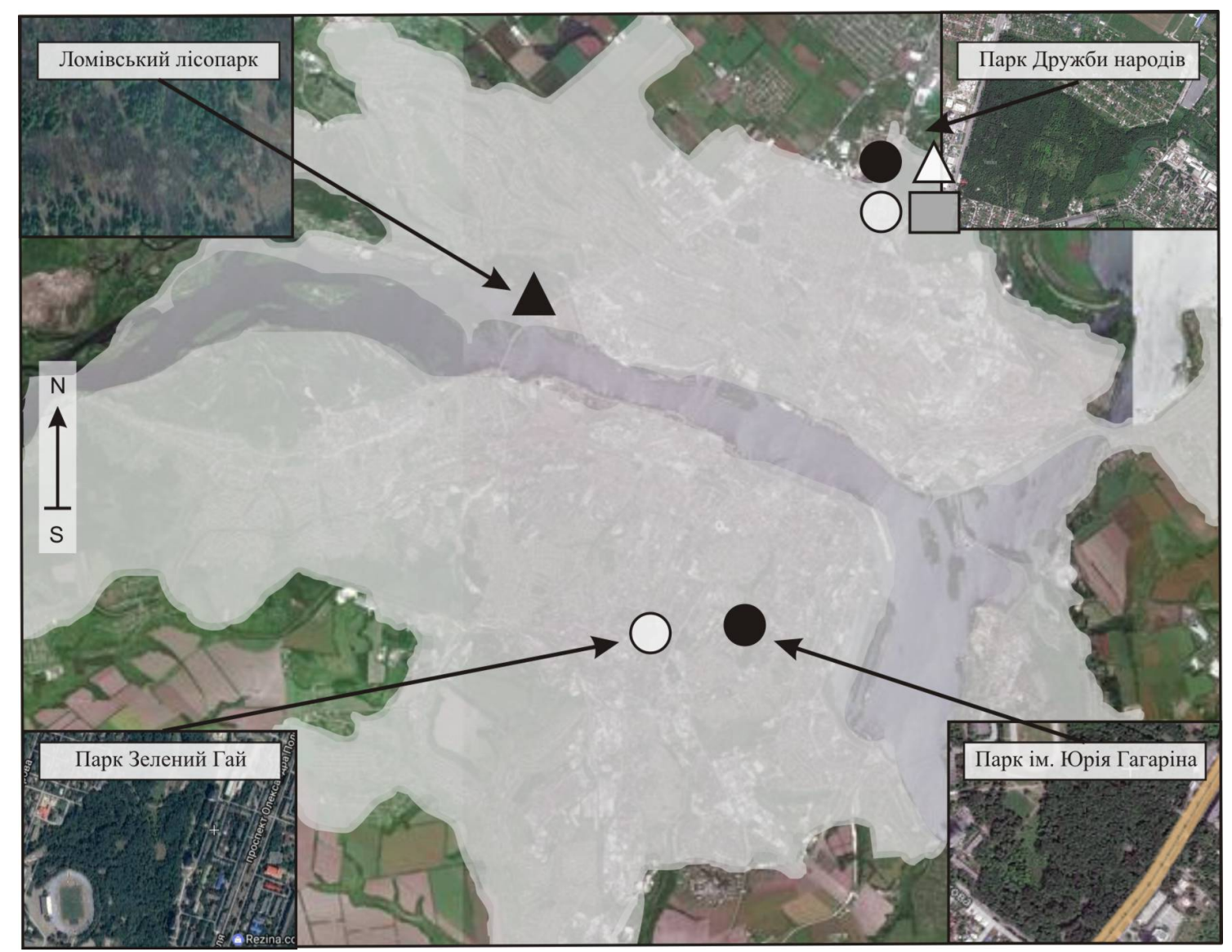

Рис. 5. Локалітети насіннєвої порослі адвентивних видів на території м. Дніпро: ваточник сирійський, $\boldsymbol{\Delta}$ - скумпія звичайна, $\Delta$ - черемха пізня, • - каркас західний, о - липа широколиста

\section{Таблиця 3}

Розподіл насіннєвого покоління скумпії звичайної за онтогенетичними групами в насадженні дуба звичайного

\begin{tabular}{lccc}
\hline \multirow{2}{*}{ Показник } & \multicolumn{3}{c}{ Онтогенетична група } \\
\cline { 2 - 4 } & ювенільні & віргінільні & генеративні \\
\hline Вік, роки & $0,5-1,0$ & $3-5$ & 7 \\
Висота, м & $0,17 \pm 0,07$ & $0,80 \pm 0,23$ & $1,50 \pm 0,35$ \\
Чисельність, $\%$ & 30 & 60 & 10 \\
\hline
\end{tabular}

На території м. Дніпро активне насіннєве відтворення C. coggygria відмічено у проектованому ландшафтному заказнику «Лівобережний» на території житлових масивів Кам'янський і Ломівський (рис. 5). У насадженні сосни звичайної (Pinus sylvestris L.), розташованому в межах піщаної тераси долини р. Дніпро, виявлено чисельні розсіяні куртини з насіннєвої та кореневої порослі C. coggygria, сформовані із рослин віком 5-7 років. Джерелом розповсюдження насіння були, ймовірно, висаджені понад 25 років тому рослини скумпії звичайної, які наразі мають задовільний життєвий стан і ростуть на відстані
50-60 м від молодих рослин. Отже, у Степовому Придніпров'і адвентивний вид $C$. coggygria натуралізувався упродовж декількох десятиліть в умовах створених насаджень, адаптувавшись до широкої амплітуди мікрокліматичних і грунтовогідрологічних умов. Активне насіннєве відтворення скумпії звичайної виявлено як у мезоксерофільних умовах зволоження на чорноземах звичайних середньогумусних, так і на бідних піщаних грунтах. Насіннєва та коренева поросль скумпії звичайної витримує досить значне затінення під наметом дубових і дубово-ясеневих насаджень. Зважаючи на високу толерантність скумпії звичайної до едафічних умов у місцезростаннях степової зони, вважаємо, що підвищення рівня інвазійності C. coggygria упродовж останніх десятиліть асоційоване зі сприятливими для адвентивного виду кліматичними змінами, зокрема зростанням температури та освітленості. Наші висновки наближені до результатів досліджень, згідно 3 якими рослинні види походженням із теплих регіонів у місцях із помірним кліматом через подовження періоду вегетації набули здатності утворювати плоди (Niinemets and Penuelas, 
2008) або конкурувати з місцевими видами, такими як Prunus laurocerasus у Центральній Європі (Berger et al., 2007).

Черемха пізня. На території Дніпропетровської області на піщаній терасі p. Оріль знайдено ділянки з численною насіннєвою порослю черемхи пізньої. У Петриківському районі у південно-східному напрямку від села Сорочине (рис. 4) під наметом насаджень сосни звичайної ( $P$. sylvestris) виявлено підріст черемхи пізньої, який складали ювенільні, віргінільні та генеративні рослини 3 максимальним віком 10-12 років. Джерелами розповсюдження насіння та фітоінвазії $P$. serotina були, ймовірно, 30-35-річні водозахисні насадження цього виду, розташовані уздовж Орільського каналу на відстані 50-100 м від куртин насіннєвої порослі. У Магдалинівському районі зафіксували незначну кількість молодих віргінільних рослин черемхи пізньої в натуралізованому масивному 70-річному сосновому насадженні (Шагарівський ліс) на піщаній терасі p. Оріль (рис. 4). Джерело розповсюдження насіння P. serotina у Шагарівському лісі не встановлене, оскільки дорослих рослин черемхи в насадженні під час досліджень не знайдено. Наявність генеративних рослин у складі насіннєвої порослі $P$. serotina підтверджує, що кліматичні зміни у Степовому Придніпров”ї протягом останніх десятиліть сприяли зростанню рівня інвазійності адвентивного натуралізованого деревного виду та його розселенню в напівприродному середовищі. Подібну тенденцію відмічено (Walther et al., 2007) для пальмової рослини Trachycarpus fortunei, яка, за рахунок пом'якшення зимових умов і зростання середньої температури найхолоднішого місяця протягом попереднього періоду на $2,0-2,8{ }^{\circ} \mathrm{C}$, виявилась здатною створити плодючі популяції у дикій природі.

Ділянки, на яких спостерігали численні молоді рослини черемхи пізньої, знайдені також на території м. Дніпро у парку Дружби народів (рис. 5), розташованому в межах IV надзаплавної тераси Дніпра на лучно-чорноземних середньовилужених потужних малогумусних важкосуглинистих грунтах.

Вік деревних насаджень парку, включаючи дорослі рослини P. serotina, становить близько 50-60 років. Масова насіннєва поросль черемхи пізньої локалізувалась на території парку у свіжуватих та свіжих умовах зволоження грунту під наметом акацієво-ясеневих насаджень 3 освітленістю нижніх фітогоризонтів на рівні $12,8 \%$ відкритих ділянок. У той самий час насіннєва поросль була відсутня на ділянках із сухуватими умовами та високою освітленістю за рахунок деструкції деревостану (70,4\% відкритих ділянок) навіть за наявності значної кількості генеративних особин $P$. serotina.

Зважаючи на високий рівень задерніння грунту травостоєм на вказаних ділянках (проективне покриття становить 70 $100 \%$ ), вважаємо задерніння грунту одним із важливих факторів, що лімітують формування насіннєвої порості черемхи пізньої в мезоксерофільних умовах. Склад підросту черемхи пізньої, віддаленого на 10-50 м від материнських рослин, представлений усіма онтогенетичними групами 3 максимальним віком особин 14-15 років, що свідчить про насіннєве відтворення адвентивного виду в урбанізованих умовах (табл. 4). Локальна популяція черемхи пізньої у парку Дружби народів має прогресивний тип із переважанням рослин віргінільної групи та наявністю значної кількості генеративних особин, що вказує на її потенційну спроможність до подальшого розселення у парку та на прилеглих територіях.

\section{Таблиця 4}

Розподіл насіннєвого покоління черемхи пізньої за онтогенетичними групами (парк Дружби народів)

\begin{tabular}{lccc}
\hline \multirow{2}{*}{ Показник } & \multicolumn{3}{c}{ Онтогенетична група } \\
\cline { 2 - 4 } & ювенільні & віргінільні & генеративні \\
\hline Вік, роки & $1-2$ & $3-8$ & $7-15$ \\
Висота, м & $0,55 \pm 0,11$ & $1,30 \pm 0,25$ & $2,80 \pm 0,58$ \\
Чисельність, \% & 32 & 53 & 15 \\
\hline
\end{tabular}

У країнах Західної та Східної Свропи P. serotina занесена до «чорного списку» (Genovesi and Scalera, 2007), оскільки проявляє значну інвазійну здатність і масово вторгається в приміські ліси та заселяє перелоги (Chabrerie et al., 2010; Wołkowycki, 2015). В Україні черемху пізню ввели в культуру i тривалий час широко використовували під час створення рекреаційних зон і захисних лісонасаджень у лісовій та лісостеповій зонах, де упродовж останніх десятиліть адвентивний вид проявив інвазійну активність у природних, напівприродних і штучних екосистемах. У Степовому Придніпров'ї черемху пізню рідко використовували в рекреаційних і захисних насадженнях, $i$ дотепер розповсюдження виду за межами території інтродукції не досліджували. Отримані результати вказують на зростання ступеня інвазійності натуралізованого адвентивного виду $P$. serotina, яке не детерміноване едафічними умовами, оскільки черемха пізня виказала високу толерантність до умов зволоження місцезростань на території Дніпропетровської області. Отже, поява чисельної насіннєвої порослі черемхи пізньої пов'язана з тим, що зміни кліматичних умов у Степовому Придніпров 'ï, які відбулись упродовж останніх десятиліть, виявились сприятливими для помітного зростання ступеня інвазійності адвентивного виду P. serotina.

Каркас західний. Цей вид для території Свропи - адвентивний. Він має тенденцію до експансії (Pyšek et al., 2012). В Україні C. occidentalis, інтродукований понад 200 років тому, останніми роками виявив здатність до успішного самовідтворення у степовій зоні. На території Дніпропетровської області існують нечисленні рекреаційні та захисні лісонасадження, в яких присутній каркас західний, що знижує кількість джерел інвазії даного адвентивного виду. Під час маршрутних досліджень у Царичанському районі поблизу с. Могилів у заплаві р. Оріль у природній берестово-липовій діброві виявлено молоді рослини C. occidentalis віком до 7 років (рис. 4). Найближчі до цієї ділянки дорослі дерева каркасу західного росли на відстані близько 400 м у прилеглому лісонасадженні, де також виявлено молоду насіннєву поросль цього виду. У Магдалинівському районі поблизу с. Чернеччина в підвищеній прирусловій зоні р. Оріль також зафіксували нечисленний підріст $C$. occidentalis (рис. 4). Насіннєва поросль каркасу західного сформувалась у природній липово-в'язовій діброві зі свіжуватим гігротопом і складалась із молодих рослин віком від 4 до 6 років.

У ході маршрутних досліджень, проведених на території м. Дніпро, виявили насіннєву поросль каркасу західного на відстані не менше 100 м від дорослих рослин у парку Дружби народів (табл. 5) і парку імені Юрія Гагаріна (рис. 5). Молоді рослини каркасу західного віком до 6-7 років знаходили під наметом 50-60-річних акацієвих та акацієво-ясеневих насаджень із досить значною світлопроникністю. Отримані результати дають підставу вважати, що насіннєве самовідтворення C. occidentalis упродовж останніх років у природних і антропогенних екотопах указує на успішну натуралізацію виду та потенційну загрозу його інвазійності у Степовому Придніпров'ї в умовах подальших кліматичних змін. В урбофітоценозах процес самовідтворення каркасу західного відбувається в умовах відсутності належного догляду за зеленими насадженнями, включаючи вирубування насіннєвої порості.

\section{Таблиця 5}

Розподіл насіннєвого покоління каркасу західного за онтогенетичними групами (парк Дружби народів)

\begin{tabular}{lccc}
\hline \multirow{2}{*}{ Показник } & \multicolumn{3}{c}{ Онтогенетична група } \\
\cline { 2 - 4 } & ювенільні & віргінільні & генеративні \\
\hline Вік, роки & 1 & $4-7$ & відсутні \\
Висота, м & $0,32 \pm 0,08$ & $1,80 \pm 0,45$ & - \\
Чисельність, $\%$ & 60 & 40 & - \\
\hline
\end{tabular}

Таким чином, зростання рівня інвазійності досліджених адвентивних рослинних видів свідчить про їх особливу чутливість до кліматичних змін, які протягом останніх десятиліть мали вплив на всю регіональну рослинність. Подібні результати отримані в експериментах із модельованими умовами потепління (Prieto et al., 2009), під час яких у восьми чагар- 
никових і трав'янистих видів рослин у різних країнах Європи виявили прискорення весняного росту. Найчутливішими до змін температури були Vassinium vulgaris та Empetrum nigrum в Уельсі, Deschamsia flexиosa у Данії, Calluna vulgaris у Нідерландах, Populus alba в Угорщині та Erica multiflora в Іспаніiі.

Виявлені тенденції розширення меж розповсюдження адвентивних рослинних видів у Степовому Придніпров"ї на фоні кліматичних змін узгоджуються із загальновідомими прогнозами (Suarez and Tsutsui, 2008) щодо загрози природному біорізноманіттю, яка посилюється у випадку зростання рівня інвазійності багатьох чужорідних видів. Фахівці наголошують на необхідності кількісних оцінок і прогнозування глобальних наслідків садівництва та міського озеленення, серед яких посилення біологічних інвазій посідає перше місце (Niinemets and Penuelas, 2008)

\section{Висновки}

Кліматичні флуктуації останніх десятиліть виявились пусковим механізмом для ініціації інвазійної здатності досліджених адвентивних рослинних видів у Степовому Придніпров”і. Наявність життєздатної порослі насіннєвого походження у натуралізованих деревних адвентивних видів далеко за межами вихідних насаджень указує на настання сприятливіших умов середовища для формування та проростання насіння та виживання підросту. Враховуючи значну сталість едафічного фактора, ми вважаємо, що ключову роль у зростанні інвазійної здатності адвентивних видів відіграли зміни кліматичних чинників, зокрема температури та зволоження. Ймовірно, T. platyphyllos у мінливих кліматичних умовах здатна розширити межі розповсюдження у зволожених екотопах i, можливо, витіснити аборигенні види. Вид C. coggygria натуралізувався упродовж декількох десятиліть і наразі проявляе здатність до утворення насіннєвої порослі в напівприродних фітоценозах. Наявність віргінільних і генеративних рослини у складі насіннєвого підросту P. serotina свідчить про успішне відтворення адвентивного виду в умовах напівприродних і урбанізованих екотопів. C. occidentalis виявився найменш чутливим до впливу кліматичних змін, однак наявність молодої насіннєвої порослі у природних і антропогенних екотопах вказує на успішну натуралізацію виду та потенційну загрозу його інвазійності у Степовому Придніпров ї в умовах подальших кліматичних змін. Виявлені закономірності необхідно враховувати під час створення лісонасаджень на території м. Дніпро та Степового Придніпров'я у цілому. Проникнення $A$. syriaca 3 рудеральних місцезростань в агроценози та катастрофічне поширення в них підвищує вірогідність гомогенізації складу сегетальних угруповань за відсутності заходів із контролю чисельності адвентивного виду.

\section{References}

Araujo, M. B., Alagador, D., Cabeza, M., Nogues-Bravo, D., \& Thuiller, W. (2011). Climate change threatens European conservation areas. Ecology Letters, 14(5), $484-492$.

Arianoutsou, M., Delipetrou, P., Vilà, M., Dimitrakopoulos, P. G., CelestiGrapow, L., Wardell-Johnson, G., Henderson, L., Fuentes, N., UgarteMendes, E., \& Rundel, P. W. (2013). Comparative patterns of plant invasions in the mediterranean biome. PLoS One, 8(11), e79174.

Bacieczko, W., \& Borcz, A. (2015). Structure of Asclepias syriaca L. population against phytocenotic and habitat conditions in Widuchowa (West Pomerania). Biodiversity: Research and Conservation, 40, 69-75.

Bahuguna, R. N., \& Jagadish, K. S. V. (2015). Temperature regulation of plant phenological development. Environmental and Experimental Botany, 111, 83-90.

Baranovski, B., Khromykh, N., Karmyzova, L., Ivanko, I., \& Lykholat, Y. (2016). Analysis of the alien flora of Dnipropetrovsk Province. Biological Bulletin of Bogdan Chmelnitskiy Melitopol State Pedagogical University, 6(3), 419-429.

Barbarich, A. I., \& Horhota, A. Y. (Ed.) (1952). Ozelenenie naselennyih mest [Landscaping of populated sites]. Akademiya Arhitektury USSR, Kiev (in Russian).
Berger, S., Söhlke, G., Walther, G.-R., \& Pott, R. (2007). Bioclimatic limits and range shifts of cold-hardy evergreen broad-leaved species at their northern distributional limit in Europe. Phytocoenologia, 37, 523-539.

Bergstrom, D. M., Lucieer, A., Kiefer, K., Wasley, J., Belbin, L., Pedersen, T. K., \& Chown, S. L. (2009). Indirect effects of invasive species removal devastate world heritage island. Journal of Applied Ecology, 46(1), 73-81.

Blackburn, T. M., Essi, F., Evans, T., Hulme, P. I., \& Jeschke, J. M. (2014). A unified classification of alien species based on the magnitude of their environmental impacts. PLoS Biology, 12(5).

Bowler, D. E., Haase, P., Kröncke, I., Tackenberg, O., Bauer, H. G., Brendel, C., Brooker, R. W., Gerisch, M., Henle, K., Hickler, T., Hof, C., Klotz, S., Kühn, I., Matesanz, S., O‘Hara, R., Russell, D., Schweiger, O., Valladares, F., Welk, E., Wiemers, M., \& Böhning-Gaese, K. (2015). A cross-taxon analysis of the impact of climate change on abundance trends in central Europe. Biological Conservation, 187, 41-50.

Brygadyrenko, V. V., \& Nazimov, S. S. (2015). Trophic relations of Opatrum sabulosum (Coleoptera, Tenebrionidae) with leaves of cultivated and uncultivated species of herbaceous plants under laboratory conditions. Zookeys, 481, 57-68.

Brygadyrenko, V. V. (2016). Evaluation of ecological niches of abundant species of Poecilus and Pterostichus (Coleoptera: Carabidae) in forests of the steppe zone of Ukraine. Entomologica Fennica, 27(2), 81-100.

Bussotti, F., Pollastrini, M., Holland, V., \& Bruggeman, W. (2015). Functional traits and adaptive capacity of European forests to climate change. Environmental and Experimental Botany, 111(3), 91-113.

Chabrerie, O., Loinard, J., Perrin, S., Saguez, R., \& Decocq, G. (2010). Impact of Prunus serotina invasion on understory functional diversity in a European temperate forest. Biological Invasions, 12(6), 1891-1907.

Genovesi, P., \& Scalera, R. (2007). Assessment of existing lists of invasive alien species for Europe, with particular focus on species entering Europe through trade, and proposed responses. In: Convention on the conservation of European wildlife and natural habitats. Strasbourg, 2629 November 2007.

Gritti, E. S., Smith, B., \& Sykes, M. T. (2006) Vulnerability of mediterranean basin ecosystems to climate change and invasion by exotic plant species. Journal of Biogeography, 33, 145-157.

Jochner, S., \& Menzel, A. (2015). Does flower phenology mirror the slowdown of global warming? Ecology and Evolution, 5(11), 2284-2295.

Knapp, S., Kuhn, I., Stolle, J., \& Klotz, S. (2009). Changes in the functional composition of a Central European urban flora over three centuries. Perspectives in Plant Ecology, Evolution and Systematics, 12(3), 235-244.

Linder, M., Fitzgerald, J. B., Zimmermann, N. E., Reyer, C., Delzon, S., Van der Maaten, E., Schelhass, M.-J., Lasch, P., Eggers, J., Van der MaatenTheunissen, M., Suckow, F., Promas, A., Poulter, B., \& Hanewinkel, M. (2014). Climate change and European forests: What do we know, what are the uncertainties, and what are the implications for forest management? Journal of Environmental Management, 146(12), 69-83.

Lykholat, Y. V., Khromykh, N., Ivanko, I., Kovalenko, I., Shupranova, L., \& Kharytonov, M. (2016a). Metabolic responses of steppe fores rees to altitude-associated local environmental shanges. Agriculture and Forestry, 62(2), 163-171.

Lykholat, Y., Alekseeva, A., Khromykh, N., Ivanko, I., Kharytonov, M., \& Kovalenko, I. (2016b). Assessment and prediction of viability and metabolic activity of Tilia platyphyllos in arid steppe climate of Ukraine. Agriculture and Forestry, 62(3), 57-64.

Menzel, A., Sparks, T. H., Estrella, N., Koch, E., Aasa, A., Ahas, R., Alm-Kubler, K., Bissolli, P., Braslavska, O., Briede, A., Chmielewski, F. M., Crepinsek, Z., Curnel, Y., Dahl, A., Defila, C., Donnelly, A., Filella, Y., Jatcza, K., Mage, F., Mestre, A., Nordli, O., Penuelas, J., Pirinen, P., Remisova, V., Scheifinger, H., Striz, M., Susnik, A., Van Vliet, A. J. H., Wielgolaski, F. E., Zach, S., \& Zust, A. (2006). European phenological response to climate change matches the warming pattern. Global Change Biology, 12, 1969-1976.

Mosyakin, S. L., \& Fedoronchuk, M. M. (1999). Vascular plants of Ukraine (Nomenclatural checklist). Naukova Dumka, Kyiv.

Mund, M., Kutsch, W. L., Wirth, C., Kahl, T., Knohl, A., Skomarkova, M. V., \& Schulze, E. D. (2010). The influence of climate and fructification on the interannual variability of steam growth and net primary productivity in an oldgrowth, mixed beech forest. Tree Physiology, 30(6), 689-704.

Niinemets, U., \& Penuelas, J. (2008). Gardening and urban landscaping: Significant players in global change. Trends in Plant Science, 13(2), 60-65.

Pauková, Ž., Káderová, V., \& Bakay, L. (2013). Structure and population dynamics of Asclepias syriaca L. in the agri-cultural land. Agriculture (Pol'nohospodárstvo), 59(4), 161-166.

Pompe, S., Hanspach, J., Badeck, F.-W., Klotz, S., Bruelheide, H., \& Kuhn, I. (2010). Investigating habitat-specific plant species pools under climate change. Basic and Applied Ecology, 11, 603-611.

Prieto, P., Penuelas, J., Niinemets, U., Ogaya, R., Schmidt, I. K., Beier, C., Tietema, A., Sowerby, A., Emmett, B. A., Lang, E. K., Kroel-Dulay, G., 
Lhotsky, B., Cesaraccio, C., Pellizzaro, G., DeDato, G., Sirca, C., \& Estiarte, M. (2009). Changes in the onset of spring growth in shrubland species in response to experimental warming along a north-south gradient tin Europe. Global Ecology and Biogeography, 18, 473-484.

Pyšek, P., Danihelka, J., Sádlo, J., Chrtek, J. Jr., Chytrý, M., Jarošík, V., Kaplan, Z., Krahulec, F., Moravcová, L., Pergl, J., Štajerová, K., \& Tichý, L. (2012). Catalogue of alien plants of the Czech Republic (2nd edition): Checklist update, taxonomic diversity and invasion patterns. Preslia, 84, 155-255.

Ramirez-Valiente, J. A., Koehler, K., \& Cavender-Bares, J. (2015). Climatic origins predict variations in photoprotective leaf pigments in response to drought and law temperature in live oaks (Quercus series virentes). Tree Physiology, 35(1), 521-534.

Richardson, D. M., Pyśek, P., Redjmanek, M., Barbour, N. G., Panetta, F. D., \& West, S. J. (2000). Naturalization and invasion of alien plants: Concepts and definitions. Diversity and Distributions, 6, 93-107.

Sperlich, D., Chang, C. T., Penuelas, J., Gracia, C., \& Sabate, S. (2015). Seasonal variability of foliar photosynthetic and morphological traits and drought impacts in a mediterranean mixed forest. Tree Physiology, 35(5), 501-520.

Suarez, A. V., \& Tsutsui, N. D. (2008). The evolutionary consequences of biological invasions. Molecular Ecology, 17(1), 351-360.

Tarasov, V. V. (2005). Flora Dnipropetrovskoy ta Zaporizkoy oblastey. Sudynni roslyny. Biologo-ekologichna harakterystyka vydiv (Monografiya) [Flora of Dnipropetrovsk and Zaporizhzhya oblasts. Vascular Plants. Biology-ecology characteristics of species]. DnipropetrovskUniversity Press, Dnipropetrovsk (in Ukrainian).
Thuiller, W., Richardson, D. M., \& Midgley, G. F. (2007). Will climate change promote alien plant invasions? In: Nentwig, W. (ed.) Ecological Studies, Biological Invasions, 193. Springer-Verlag Berlin, Heidelberg, 197-211.

Urban, M. C, Tewksbury, J. J, \& Sheldon, K. S. (2012). On a collision course: Competition and dispersal differences create no-analogue communities and cause extinctions during climate change. Proceedings of the Royal Society B, 279(1735), 2072-2080.

Van der Veken, S., Hermy, M., Vellend, M., Knapen, A., \& Verheyen, K. (2008). Garden plants get a head start on climate change. Frontiers in Ecology and the Environment, 6(4), 212-216.

Vilà, M., Basnou, C., Pyšek, P., Josefsson, M., Genovesi, P., Gollasch, S., Nentwig, W., Olenin, S., Roques, A., Roy, D., \& Hulme, P. I. (2010). How well do we understand the impacts of alien species on ecological services? A pan-European cross-taxa assessment. Frontiers in Ecology and the Environment, 8(3), 135-144.

Walther, G. R., Gritti, E. S., Berger, S., Hickler, T., Tang, Z., \& Sykes, M. T. (2007). Palms tracking climate change. Global Ecology and Biogeography, 16(6), 801-809.

Walther, G.-R., Roques, A., Hulme, P. E., Sykes, M. T., Pysek, P., Kuhn, I, \& Zobel, M. (2009). Alien species in a warmer world: Risks and opportunities. Trends in Ecology and Evolution, 24(12), 686-693.

Wołkowycki, D., \& Próchnicki, P. (2015). Spatial expansion pattern of black cherry Padus serotina Ehrh. in suburban zone of Białystok (NE Poland). Biodiversity Research and Conservation, 40(1), 59-67. 